\title{
Crianças que Cuidam de Crianças / Children who Take Care of Children
}

https://doi.org/10.21814/uminho.ed.36.20

\section{Elena Colonna}

Universidade Eduardo Mondlane, Moçambique 



\section{Crianças que Cuidam de Crianças}

As crianças que cuidam de crianças são aquelas que, de forma regular ou ocasional, assumem responsabilidades de cuidado em relação a outras crianças, desafiando a visão dominante de infância que as considera apenas enquanto objeto de cuidado dos adultos. Em resposta a um Manual de Teoria e Pesquisa da Socialização de 1969, que nas suas 1.189 páginas não incluía nenhuma referência aos cuidados de crianças realizados por pessoas diferentes dos progenitores, Weisner e Gallimore (1977) são os primeiros a dar visibilidade científica a este fenómeno, no seu famoso artigo My Brother's Keeper: Child and Sibling Caretaking. Segundo estes autores, as evidências transculturais indicavam que os cuidados não parentais eram a norma ou uma forma de cuidado significativa na maioria das sociedades, mas sistematicamente negligenciados na pesquisa e nas teorias sobre socialização, embasadas na realidade dos países industrializados ocidentais, onde as mães representavam as cuidadoras principais.

O conceito de criança e irmão que toma conta [child and sibling caretaking] inclui todos os tipos de socialização e responsabilidades rotineiras que uma criança assume por outras. "Tomar conta" refere-se a atividades que variam do cuidado completo e independente a tempo inteiro de uma criança por parte de outra criança mais velha, no desempenho de tarefas específicas para outra criança sob a supervisão de adultos ou outras crianças. Estas atividades podem incluir orientação do comportamento da criança mais nova, através de ordens verbais e outras orientações explícitas, assim como "dar uma olhada aos irmãos mais novos" (Weisner \& Gallimore, 1977, p. 169). 0 cuidado de crianças por parte de outras crianças pode acontecer de diferentes formas: dentro do agregado familiar assume, geralmente, uma modalidade informal, enquanto em contextos extrafamiliares e, às vezes, institucionais, pode haver contratualização ou "troca" de crianças para prover cuidados a crianças mais novas.

Os jovens cuidadores atuam entre dois conjuntos simultâneos de pressões e aprendem a criar um equilíbrio entre eles: por um lado, procuram interpretar as exigências e os comportamentos das crianças sob o seu cuidado e, por outro lado, tentam entender as expectativas e as regras sociais dos adultos. Em linha com a ideia da reprodução interpretativa, as crianças que 
cuidam de outras crianças observam as práticas de cuidados dos seus pais e dos outros adultos, entretanto o seu estilo de cuidados acaba sendo diferente, devido à interpretação que as crianças fazem das atividades dos adultos e aos novos elementos que acrescentam, tanto individualmente como em grupo de pares.

Desde o trabalho pioneiro de Weisner e Gallimore (1977), diferentes pesquisas têm sido desenvolvidas sobre as crianças que cuidam de crianças, sobretudo nas sociedades do mundo maioritário, na Ásia, na África e na América Latina.

Por exemplo, Colonna (2012) procurou compreender o fenómeno das crianças que cuidam de outras crianças num bairro periférico da cidade de Maputo, em Moçambique, a partir dos pontos de vista das crianças que nele participam, tanto como cuidadoras, como destinatárias dos cuidados. Por um lado, esta prática desempenha um papel central na sobrevivência e na reprodução das famílias, permitindo aos adultos dedicarem-se a outras atividades como tarefas domésticas, trabalho remunerado e negócios. Por outro lado, cuidar de outras crianças implica também negociar identidades e criar relações, muitas vezes de natureza variável e ambivalente. A multiplicidade de relações identificáveis nas práticas das crianças pode ser enquadrada em três tipos principais: relações de poder, relações de aprendizagem e relações afetivas e lúdicas. Os primeiros dois tipos de relações tendem a ser mais hierárquicos e verticais, enquanto o terceiro é marcado por maior simetria e horizontalidade.

O estudo das crianças que cuidam de crianças em Moçambique contribui também para o reconhecimento das crianças enquanto atores sociais. Nota-se que as crianças mais novas participam nas negociações quotidianas para definir os seus cuidadores e, na ausência dos adultos (e às vezes até na sua presença), expressam a sua preferência pelos cuidados dos irmãos ou das outras crianças mais velhas da família. As crianças mais velhas reconhecem-se como as pessoas mais apropriadas para cuidarem dos irmãos mais novos, quando os pais não estão conscientes da importância da sua contribuição e muitas vezes desempenhando esta atividade com orgulho (Colonna, 2012).

Uma pesquisa com adolescentes mexicanos-americanos mostrou que o cuidado frequente de irmãos estava relacionado com aspirações educativas mais elevadas, com maiores tendências pró-sociais e a mais envolvimento escolar, mas também com mais elevado absentismo. Entretanto, quando 
esta prática estava associada a atitudes estereotipadas relativamente ao sexo por parte das mães e a fortes crenças familísticas, os jovens cuidadores, principalmente as meninas, mostravam um pior desempenho escolar e menores aspirações educativas (East \& Hamill, 2013).

Estudar as crianças que cuidam de crianças em diferentes contextos do mundo representa um campo fértil para a Sociologia da Infância, ainda largamente inexplorado. Numa perspetiva interpretativa, este fenómeno permite observar de que forma as crianças cuidadoras utilizam recursos, estratégias e estilos dos adultos, cruzando-os com elementos próprios das suas culturas de pares, da sua forma de ser enquanto crianças. Na abordagem estrutural, é relevante compreender a relação entre o cuidar de crianças e outras variáveis sociais e económicas, como o género, a idade, a classe social, o país de origem, a frequência escolar, entre outros. Finalmente, é fundamental cruzar o cuidar de crianças com os direitos das crianças. Se os estudos mostram que as crianças que cuidam de crianças podem ganhar em termos de participação, adquirindo competências, habilidades e autoconfiança, o impacto na proteção e na provisão, por exemplo da educação e da saúde, necessita, ainda, de ser investigado.

\section{Children who Take Care of Children}

Children who take care of children are those who in some way, and for some period, are caregivers of other children, challenging the dominant view of childhood that considers them only objects of adult care. In response to a 1969 Handbook of Socialization Theory and Research, with no reference in its 1,189 pages to childcare by people other than parents, Weisner and Gallimore (1977) were the first to give scientific visibility to this phenomenon, in their famous article My Brother's Keeper: Child and Sibling Caretaking. According to these authors, cross-cultural evidence indicated that non-parental care was either the norm or a significant form of care in most societies. However, these practices were systematically neglected in research and theories on socialization, based on the reality of Western industrialized countries, where mothers represented the main caregivers.

The concept of child and sibling caretaking includes "all kinds of socialization, training, and routine responsibilities one child assumes for others. 'Caretaking' refers to activities ranging from complete and independent full-time care of a child by an older child to the performance of specific tasks for another child under the supervision of adults or other children; it 
includes verbal or other explicit training and direction of the child's behavior, as well as simply 'keeping an eye out for' younger siblings" (Weisner \& Gallimore, 1977, p. 169). The care of children by other children can happen in an informal and non-institutionalized way within the household itself, as well as through the hiring or exchange of children to provide care in an extra-family and, sometimes, institutional context.

Young caregivers act between two simultaneous sets of pressures, those of the children in their charge and those of their parents, and they must learn to create a balance, interpreting properly the behaviors of the younger ones and trying to understand the often-complex social rules of adults. In line with the idea of interpretative reproduction, children who take care of children may be consciously trying to imitate their parents' care style. However, results have generally been very different, taking into account children's interpretation of adult activities and the new elements that they add both individually as well as within their group of peers.

Since the pioneering work of Weisner and Gallimore (1977), different research has been carried out on children who take care of other children, especially in societies in the majority world, in Asia, Africa and Latin America. For example, Colonna (2012) tried to understand the phenomenon of children who care for other children in the suburbs of Maputo, in Mozambique, from the children's points of view, listening to both caregivers and children in charge. On the one hand, this practice plays a central role in the survival and reproduction of families, allowing adults to engage in other activities such as household chores, paid work and business. On the other hand, taking care of other children also involves negotiating identities and creating relationships, often variable and ambivalent. The multiplicity of relationships observed in children's practices can be framed in three main types: power relationships, learning relationships, and affective and playful relationships.

The study of children who take care of children in Mozambique also contributes to the recognition of children as social actors. It is noted that younger children participate in daily negotiations to define their caregivers and, in the absence of adults (and sometimes even in their presence), they express their preference for the care of siblings or other older children in the family. Simultaneously, older children recognize themselves as the most appropriate people to care for younger siblings when parents are absent, they are aware of the importance of their contribution and they often fulfil this duty with pride (Colonna, 2012). 
A survey with Mexican American teenagers showed that frequent sibling care was related to higher educational aspirations, greater prosocial tendencies and more school involvement, but also a greater number of absences. However, when this practice was associated with mothers' gender-stereotyped attitudes and strong family beliefs, young caregivers, especially girls, showed poorer school performance and lower educational aspirations (East \& Hamill, 2013).

Studying children who take care of children in different contexts of the world represents a fertile field for the Sociology of Childhood, still largely unexplored. In an interpretive perspective, this phenomenon allows us to observe how the caretaking children use resources, strategies and styles of adults, integrating them with elements of their peer cultures and their way of being as children. In a structural approach, it is relevant to understand the relationship between childcare and other social and economic variables, such as gender, age, social class, country of origin, school attendance, among others. Finally, it is essential to connect child and sibling caretaking with children's rights. If evidence shows that children who take care of children may gain in terms of participation, acquiring skills, abilities and self-confidence, the impact on protection and provision, for example in education and health, needs to be further investigated.

\section{Referências / References}

Colonna, E. (2012). Eu é que fico com a minha irmã. Vida quotidiana das crianças na periferia de Maputo. [Tese de doutoramento não publicada], Instituto de Educação da Universidade do Minho, Braga.

East, P. \& Hamill, S. (2013). Sibling caretaking among Mexican American youth: Conditions that promote and hinder personal and school success. Hispanic Journal of Behavioral Sciences, 35(4), 542-564.

Weisner, T. \& Gallimore, R. (1977). My brother's keeper: Child and sibling caretaking. Current Anthropology, 18(2), 169-190. 